\title{
Potential of oak acorn with and without polyethylene glycol as an alternative to corn in broiler diets
}

F. Saeidi, M. Houshmand", S. Parsaei \& M. Zarrin

Department of Animal Science, Yasouj University, Yasouj, Iran

(Received 14 February 2017; Accepted 24 May 2017; First published online 16 October 2017)

\author{
Copyright resides with the authors in terms of the Creative Commons Attribution 4.0 South African License. \\ See: http://creativecommons.org/licenses/by/4.0/za \\ Condition of use: The user may copy, distribute, transmit and adapt the work, but must recognize the authors and the South African \\ Journal of Animal Science.
}

\begin{abstract}
This study was conducted to investigate the potential for replacing corn with oak acorn $(O A)$, a tanninrich feedstuff, and the possible role of polyethylene glycol (PEG) in reducing detrimental effects of OA on broilers. A $3 \times 2$ factorial arrangement of treatments was used with three levels of $O A(0,150$, and $200 \mathrm{~g} / \mathrm{kg}$ diet), with and without $10 \mathrm{~g} / \mathrm{kg}$ PEG. A total of 528 one-day-old male and female Cobb 500 broiler chicks were randomly assigned to one of six experimental treatments, with four replicates of 22 birds each. OA was included in the starter (days 1-21) and finisher (days 22-42) diets as a replacement for corn, without changing the dietary levels of other ingredients. The results indicated that dietary inclusion of $O A$, without PEG, significantly reduced bodyweight gain (BWG) overall (days 1-42) and resulted in worse finisher and overall feed conversion ratios (FCR). PEG had no significant effect on the performance of birds fed diets without OA, but improved overall the BWG of birds receiving 150 and $200 \mathrm{~g} / \mathrm{kg} \mathrm{OA}$ as well as finisher and overall the FCR of birds given $150 \mathrm{~g} / \mathrm{kg} \mathrm{OA}$. Liver and pancreas weights were not significantly influenced by OA level, PEG or their interaction. Feeding with $200 \mathrm{~g} / \mathrm{kg}$ OA had deleterious effects on some tibia traits. In conclusion, a significant interaction between OA level and PEG indicates that PEG has the potential to reduce the adverse effects of $O A$, leading to improved performance. Thus, up to $150 \mathrm{~g} / \mathrm{kg}$ OA could be included in PEG-supplemented diets, without adverse effects on performance or the tibia traits of broilers.
\end{abstract}

Keywords: High-tannin feedstuff, performance, poultry nutrition, tibia characteristic

"Corresponding author: hooshmand@yu.ac.ir

\section{Introduction}

Corn is a traditional energy source in poultry nutrition. However, it is an expensive feed ingredient in developing countries. Hence, finding a new local feedstuff is important. Oak is a common tree in the forests of some regions of the world, such as Iran. Therefore, huge amounts of acorns (seed) are produced, annually. Since OA contains high levels of carbohydrates, particularly nitrogen-free extract (NFE) compounds (Bouderoua et al., 2009), it could be used as an alternative to corn in poultry diets.

Because of the lower price of $O A$, this replacement may reduce ration costs, resulting in greater benefits to producers. Recently, Sinaei \& Houshmand (2016) reported that up to $250 \mathrm{~g} / \mathrm{kg}$ OA could be included in broiler diets without adverse effects on their performance. The findings of Bouderoua et al. (2009) indicated that broilers fed diets containing $335 \mathrm{~g} / \mathrm{kg}$ OA had similar performances to those fed corn. In another study, dietary inclusion of $50,100,150$, and $200 \mathrm{~g} / \mathrm{kg}$ OA as an energy source had no deleterious effect on BWG, feed intake and FCR of Japanese quail (Midilli et al., 2008).

Unfortunately, OA usage in poultry diets is limited by the presence of high levels of tannins (Houshmand et al., 2015; Rezaei \& Semnaninejad, 2016). Tannins are water-soluble polyphenolic compounds with a molecular weight between 500 and $3000 \mathrm{Da}$, which are capable of precipitating alkaloids, gelatine and other proteins from aqueous solutions. They are usually divided into hydrolysable and condensed tannins (Jansman, 1993). Various parameters, such as diet palatability, feed intake, BWG, feed efficiency (Medugu et al., 2012) and nutrient availability (carbohydrates, proteins, minerals and vitamins) are influenced negatively by tannins (Jansman, 1993). In addition, they have deleterious consequences for internal organs such as the intestines, liver, and pancreas (Ortiz et al., 1994). Recently, it was reported that feeding broilers diets containing 100 and $200 \mathrm{~g} / \mathrm{kg}$ OA significantly reduced their performance, impaired the ileal digestibility of nutrients (dry matter (DM) and crude protein (CP)), and had deleterious effects on intestinal morphology (Rezaei \& Semnaninejad, 2016). In another study, dietary inclusion of $150 \mathrm{~g} / \mathrm{kg}$ OA 
had detrimental consequences on performance and tibia bone characteristics of broiler chickens (Houshmand et al., 2015).

Indeed, dietary minerals availability is adversely influenced by tannins (Hassan et al., 2003; Mahmood et al., 2014). Because minerals, particularly calcium and phosphorus, have essential roles in bone formation and health (Proszkowiec-Weglarz \& Angel, 2013), it is expected that feeding with high-tannin feedstuff would have a negative effect on bone health and status.

In view of the adverse effects of tannins, various methods (physical, chemical, biological) are used to alleviate them on poultry. Supplementation with tannin-biding agents such as PEG is one of these strategies (Medugu et al., 2012). PEG can form complexes with tannins, thereby preventing the binding of tannins with dietary nutrients (Mansoori et al., 2007b). The beneficial effects of PEG in reducing the negative effects of tannins in ruminants have been indicated (Mlambo et al., 2015). However, supplementation with PEG increased the nitrogen digestibility in chicks fed high-tannin sorghum (Ford \& Hewitt, 1979). Conversely, Karunajeewa et al. (1990) did not find significant interactions between various dietary levels of rapeseed meal (a feedstuff with 20-30 $\mathrm{g} / \mathrm{kg}$ tannins) and PEG in broilers. Various authors have reported beneficial effects of PEG in reducing the adverse consequences of tannic acid (TA) on performance (Mansoori et al., 2007a) and intestinal absorption of D-xylose in broilers (Mansoori et al., 2007b, Mansoori \& Modirsanei, 2012).

There are inconsistent results on the effects of dietary inclusion of $O A$ in broiler nutrition. Additionally, there is limited information about the influence of supplemental PEG on broilers that are given high-tannin feedstuffs such as OA. Thus, the current study was designed to investigate the potential of OA as an alternative to corn in broiler diets and the possible role of PEG in improving the nutritive value of this feedstuff for broiler chickens.

\section{Materials and Methods}

All procedures used in the current study were approved by the Institution Animal Care Committee of Yasouj University. A total of 528 one-day-old male and female Cobb 500 broiler chicks were purchased from a local commercial hatchery and transferred to the rearing place. Upon arrival, birds were randomly distributed among 24 floor pens. A completely randomized design with factorial arrangement was used. The effects of two factors were investigated: the dietary level of OA $(0,150$, and $200 \mathrm{~g} / \mathrm{kg}$ ); and PEG supplementation (with and without). The birds were assigned to six experimental groups with four replicate pens, each with 22 chicks. They received one of these diets: a corn-based diet $(0 \mathrm{~g} / \mathrm{kg})$, and diets containing 150 or $200 \mathrm{~g} / \mathrm{kg} \mathrm{OA}$, with and without PEG (+P, $-\mathrm{P})$. The OA was included in the starter (days 1-21) and finisher (days 22-42) diets as a replacement for corn, without changing the dietary level of other feed ingredients.

Management conditions such as house temperature, lighting schedule, and vaccination were similar for all experimental groups. Feed and water were provided ad libitum during the rearing period. Feed formulation was designed to meet or exceed the nutrient requirements of broilers, based on NRC (1994) recommendations (Table 1). At 21 and 42 days of age, all birds in each pen were weighed as a group. In addition, the weight of remaining feed in feeders was determined. Collected data was used to calculate bodyweight gain (BWG) and FCR by adjusting mortality.

An adequate amount of $\mathrm{OA}$ as whole fruit was collected from the oak trees (Quercus brantii Lindl) in the forests of Yasouj, Kohgiluyeh and Boyer-Ahmad Province, Iran. After the seed coats were removed, they were dried in shade and ground with a mill grinder. The OA was analysed for DM, ether extract (EE), crude fibre (CF), CP, ash and NFE contents (AOAC, 1995, 950.2). To measure the phenolic components of OA, in the first stage the extraction process was done. The extracts were analysed according to the procedure of Makkar (2003). In this procedure, the content of total phenols, non-tannin phenols and condensed tannins was measured using Folin-Ciocalteu, polyvinylpyrrolidone and butanol-HCl-Fe reagents, respectively.

On days 21 and 42 (end of the starter and finisher phases of the study, respectively), six birds (three males and three females) from each treatment were sacrificed by cervical dislocation. Immediately the digestive system was removed carefully and the weights of liver and pancreas were measured. The relative organ weight was calculated and expressed as a percentage of live bodyweight. In addition, at the same time (days 21 and 42), the tibia bones were removed as drumsticks, placed in plastic bags and stored at -20 ${ }^{\circ} \mathrm{C}$ until further investigation. At the proper time, the samples were taken out, thawed, boiled for $10 \mathrm{~min}$, and then left to cool. After removing the adhering soft tissues, the bones were dried for 24 hours at room temperature and then parameters such as tibia weight, length and volume were measured.

The tibia bones were then dried in a drying oven at $105^{\circ} \mathrm{C}$ for 24 hours. The dry bones were ashed in a furnace at $550{ }^{\circ} \mathrm{C}$ for 24 hours. Bone ash was expressed as a percentage of bone dry weight. The tibia bone ash weight / tibia bone length index was calculated by dividing the tibia ash weight by its length (Seedor et al., 1991). The tibia robusticity index was calculated with this formula: tibia length / cube root of 
tibia weight (Reisenfeld, 1972). The calcium and phosphorus contents of the tibia bones were determined by flame atomic absorption spectrophotometry and molybdo-vanadate methods, respectively (AOAC, 1995). Data were analysed by analysis of variance using the general linear model (GLM) procedures of SAS software (SAS Institute, 2005). The means were compared with Duncan's multiple range test. The level of statistical significance was set at $P \leq 0.05$.

Table 1 Ingredient and nutrient composition of the starter and finisher diets ${ }^{1}$

\begin{tabular}{|c|c|c|}
\hline Ingredient (g/kg) & Starter & Finisher \\
\hline Corn & 560.4 & 618.9 \\
\hline Soybean meal & 371.7 & 312. 4 \\
\hline Calcium carbonate & 12.5 & 13. 6 \\
\hline Dicalcium phosphate & 16.2 & 11.5 \\
\hline Vegetable oil & 28.6 & 34.6 \\
\hline Vitamin premix ${ }^{2}$ & 2.5 & 2.5 \\
\hline Mineral premix ${ }^{3}$ & 2.5 & 2.5 \\
\hline Salt & 4.2 & 3.2 \\
\hline DL-Methionine & 1.4 & 0.60 \\
\hline L- Lysine & - & 0.20 \\
\hline \multicolumn{3}{|c|}{ Nutrient composition } \\
\hline ME (Kcal/kg) & 2950 & 3050 \\
\hline Crude protein (g/kg) & 212. 0 & 190.6 \\
\hline Calcium (g/kg) & 9.3 & 8.6 \\
\hline Available phosphorus (g/kg) & 4.2 & 3.3 \\
\hline Sodium $(\mathrm{g} / \mathrm{kg})$ & 1.8 & 1.4 \\
\hline Methionine (g/kg) & 4.6 & 3.6 \\
\hline Lysine $(\mathrm{g} / \mathrm{kg})$ & 10.1 & 9.5 \\
\hline \multicolumn{3}{|c|}{$\begin{array}{l}\text { In diets containing OA, corn was replaced with } 150 \text { and } 200 \mathrm{~g} / \mathrm{kg} \mathrm{OA} \text {, without changing the percentage of other feed } \\
\text { ingredients } \\
{ }^{2} \text { Vitamin premix provided per kilogram of diet: vitamin } \mathrm{A} \text { (retinyl acetate), } 8,000 \mathrm{IU} \text {; vitamin } \mathrm{D}_{3}, 1,000 \mathrm{IU} \text {; vitamin } \mathrm{E} \text { (DL- } \alpha \text { - } \\
\text { tocopherol), } 68 \mathrm{mg} ; \text { vitamin } \mathrm{K}_{3}, 2.5 \mathrm{mg} \text {; vitamin } \mathrm{B}_{1}, 2 \mathrm{mg} ; \text { vitamin } \mathrm{B} 2,5 \mathrm{mg} \text {; vitamin } \mathrm{B}_{6}, 2 \mathrm{mg} \text {; vitamin } \mathrm{B}_{12}, 0.01 \mathrm{mg} \text {; } \\
\text { niacin, } 30 \mathrm{mg} ; \mathrm{d} \text {-biotin, } 0.045 \mathrm{mg} ; \text { vitamin } \mathrm{C}, 50 \mathrm{mg} ; \mathrm{d} \text {-pantothenate, } 8 \mathrm{mg} \text {, folic acid, } 0.5 \mathrm{mg} \\
{ }^{3} \mathrm{Mineral} \text { premix provided per kilogram of diet: } \mathrm{Mn}, 70 \mathrm{mg} ; \mathrm{Fe}, 35 \mathrm{mg} ; \mathrm{Zn}, 70 \mathrm{mg} ; \mathrm{Cu}, 8 \mathrm{mg} ; \mathrm{I}, 1 \mathrm{mg} \text {, Se, } 0.25 \mathrm{mg} ; \mathrm{Co}, 0.2 \\
\mathrm{mg} \\
\text {-: not measured; ME: metabolizable energy }\end{array}$} \\
\hline
\end{tabular}

\section{Results and Discussion}

A proximate analysis of $O A$ is shown in Table 2. The findings show that Iranian $O A$ has a high level of NFE (664.6 g/kg DM). Thus, it may be used as an energy source in poultry diets. Consistent with this result, Shimada (2001) reported that NFE was the major component of nutrients (874-903 g/kg DM) in three species of acorn. CP content of OA $(61 \mathrm{~g} / \mathrm{kg})$ was lower than corn $(81 \mathrm{~g} / \mathrm{kg})$. Previously, Saffarzadeh et al. (1999) has reported that Iranian OA (Quercus brantii) contained $916.7 \mathrm{~g} / \mathrm{kg} D \mathrm{DM}, 39.3 \mathrm{~g} / \mathrm{kg} \mathrm{CP}, 3.7 \mathrm{~g} / \mathrm{kg} \mathrm{CF}$, $77 \mathrm{~g} / \mathrm{kg} \mathrm{EE}, 15 \mathrm{~g} / \mathrm{kg}$ ash, $751.7 \mathrm{~g} / \mathrm{kg} \mathrm{NFE}$, and $588 \mathrm{~g} / \mathrm{kg}$ starch. Table 3 shows that OA contains considerable levels of total phenols, including tannins. The results of chemical composition and the content of phenolic compounds of Iranian OA are in line with a recent study on this species (Houshmand et al., 2015).

The effects of dietary OA level and PEG on BWG, feed intake and FCR of broilers at various phases of the study are given in Table 4. During the starter phase (days 1-21), feeding with OA significantly reduced BWG. Hence, birds fed the diet without OA $(0 \mathrm{~g} / \mathrm{kg})$ had the highest BWG, followed by those fed 150 and 200 $\mathrm{g} / \mathrm{kg} O A$, respectively. The detrimental effect of OA on BWG was also observed during the finisher phase (days 22-42). Because of this effect, the highest final bodyweight $(1988 \mathrm{~g})$ was observed in $0 \mathrm{~g} / \mathrm{kg} \mathrm{OA}$, which was significantly higher than $150(1643 \mathrm{~g})$ and $200 \mathrm{~g} / \mathrm{kg}$ OA $(1569 \mathrm{~g})$. 
Table 2 Proximate analysis of oak acorn ( $\mathrm{g} / \mathrm{kg}$ dry matter)

\begin{tabular}{lcccccc}
\hline Component & DM & Ash & CP & EE & CF & NFE \\
\hline Level & $870 \pm 7.2$ & $21.8 \pm 0.14$ & $61 \pm 3.7$ & $68 \pm 0.57$ & $54.6 \pm 0.62$ & $664.6 \pm 3.8$
\end{tabular}

DM: dry matter, CP: crude protein, EE: ether extract, CF: crude fibre, NFE: nitrogen free extract

Values are means \pm SE of three replicates

Table 3 Phenolic compounds of oak acorn ( $\mathrm{g} / \mathrm{kg}$ dry matter)

\begin{tabular}{|c|c|c|c|c|c|}
\hline Component & Total phenols & $\begin{array}{l}\text { Non- tannin } \\
\text { phenols }\end{array}$ & Total tannins & Hydrolysable tannins & Condensed tannins \\
\hline Level & $80.4 \pm 0.25$ & $19.7 \pm 0.06$ & $60.6 \pm 0.31$ & $9.0 \pm 0.65$ & $51.6 \pm 0.68$ \\
\hline
\end{tabular}

Values are means \pm SE of 3 replicates.

Table 4 Effects of oak acorn level and polyethylene glycol on bodyweight gain feed intake and feed conversion ratio of broilers at different phases of the study

\begin{tabular}{|c|c|c|c|c|c|c|c|c|c|c|c|}
\hline \multirow{2}{*}{ Parameter } & \multicolumn{3}{|c|}{$\begin{array}{c}\begin{array}{c}\text { Dietary level of OA } \\
(\mathrm{g} / \mathrm{kg})\end{array} \\
\end{array}$} & \multirow{2}{*}{ SEM } & \multirow{2}{*}{$\begin{array}{c}P \\
\text { value }\end{array}$} & \multicolumn{2}{|c|}{ PEG } & \multirow{2}{*}{ SEM } & \multirow{2}{*}{$\begin{array}{c}\mathbf{P} \\
\text { value }\end{array}$} & \multirow{2}{*}{ Interaction } & \multirow{2}{*}{$\underset{\text { value }}{P}$} \\
\hline & 0 & 150 & 200 & & & Without & with & & & & \\
\hline \multicolumn{12}{|c|}{ Bodyweight gain (g) } \\
\hline d $1-21$ & $719^{a}$ & $648^{\mathrm{b}}$ & $605^{\mathrm{c}}$ & 11 & 0.0001 & 647 & 667 & 9 & 0.11 & NS & 0.18 \\
\hline d 22-42 & $1229^{a}$ & $953^{\mathrm{b}}$ & $924^{b}$ & 24 & 0.0001 & $994^{b}$ & $1076^{\mathrm{a}}$ & 20 & 0.008 & NS & 0.06 \\
\hline d $1-42$ & $1948^{\mathrm{a}}$ & $1602^{b}$ & $1529^{b}$ & 28 & 0.0001 & $1642^{b}$ & $1745^{\mathrm{a}}$ & 23 & 0.005 & * & 0.04 \\
\hline \multicolumn{12}{|c|}{ Feed intake (g) } \\
\hline d $1-21$ & 986 & 986 & 972 & 13 & 0.68 & 984 & 979 & 11 & 0.74 & NS & 0.91 \\
\hline d 22-42 & 2864 & 2868 & 2807 & 92 & 0.87 & 2883 & 2809 & 75 & 0.50 & NS & 0.19 \\
\hline d 1-42 & 3850 & 3854 & 3779 & 64 & 0.82 & 3867 & 3788 & 77 & 0.48 & NS & 0.19 \\
\hline \multicolumn{12}{|c|}{ Feed conversion ratio } \\
\hline d $1-21$ & $1.373^{\mathrm{C}}$ & $1.521^{b}$ & $1.610^{\mathrm{a}}$ & 0.02 & 0.0001 & $1.530^{\mathrm{a}}$ & $1.478^{\mathrm{b}}$ & 0.016 & 0.03 & NS & 0.13 \\
\hline d 22-42 & $2.330^{\mathrm{b}}$ & $3.070^{\mathrm{a}}$ & $3.040^{\mathrm{a}}$ & 0.115 & 0.0003 & $2.983^{\mathrm{a}}$ & $2.634^{\mathrm{b}}$ & 0.094 & 0.015 & * & 0.01 \\
\hline d $1-42$ & $1.970^{b}$ & $2.431^{\mathrm{a}}$ & $2.475^{\mathrm{a}}$ & 0.066 & 0.0001 & $2.400^{\mathrm{a}}$ & $2.186^{\mathrm{b}}$ & 0.054 & 0.011 & * & 0.01 \\
\hline
\end{tabular}

${ }_{\mathrm{A}, \mathrm{b}, \mathrm{C}}$ Means in each row with different superscripts are significantly different at $P \leq 0.05$

OA: oak acorn, PEG: polyethylene glycol

NS: not significant

*: significant

Values are means of four replicate pens, with 22 birds each

Overall (days 1-42) BWG was significantly influenced by interaction between dietary OA level and PEG (Table 5). The highest overall BWG was observed in birds fed diets without OA (with and without PEG) $(P \leq 0.05)$. Dietary inclusion of 150 and particularly $200 \mathrm{~g} / \mathrm{kg} O A$ resulted in significant reductions in overall BWG $(P \leq 0.05)$. Significant interaction indicated that broilers' response to PEG was influenced by dietary level of OA. Although PEG had no beneficial effect on BWG of birds given diet without OA, supplementation with this additive significantly reduced the detrimental effects of OA on BWG. Due to this positive effect, treatment $150+\mathrm{P}$ gained more than $150-\mathrm{P}$ and $200-\mathrm{P}(P \leq 0.05)$. Additionally, treatment $200+\mathrm{P}$ had more BWG than 200-P.

Polyethylene glycol had no significant effect on BWG, from 1 to 21 days of age but increased BWG from 22 to 42 days of age (Table 4). 
Table 5 Interaction effects of oak acorn level and polyethylene glycol on overall (days 1-42) bodyweight gain and overall feed conversion ratio of broilers

\begin{tabular}{|c|c|c|c|c|}
\hline \multirow{2}{*}{ Item } & \multirow{2}{*}{ PEG } & \multirow{2}{*}{ Overall BWG (g) (days 1-42) } & \multicolumn{2}{|c|}{ FCR } \\
\hline & & & Finisher (days 22-42) & Overall (days 1-42) \\
\hline \multicolumn{5}{|c|}{ Dietary level of $O A(\mathrm{~g} / \mathrm{kg})$} \\
\hline \multirow[b]{2}{*}{0} & Without & $1956^{a}$ & $2.300^{d}$ & $1.942^{d}$ \\
\hline & With & $1940^{\mathrm{a}}$ & $2.360^{d}$ & $1.997^{d}$ \\
\hline \multirow{2}{*}{150} & Without & $1502^{\mathrm{cd}}$ & $3.552^{\mathrm{a}}$ & $2.702^{\mathrm{a}}$ \\
\hline & With & $1704^{b}$ & $2.601^{\mathrm{cd}}$ & $2.160^{\text {cd }}$ \\
\hline \multirow{2}{*}{200} & Without & $1464^{d}$ & $3.137^{\mathrm{ab}}$ & $2.547^{\mathrm{ab}}$ \\
\hline & With & $1591^{\mathrm{bc}}$ & $2.955^{\mathrm{bc}}$ & $2.402^{\mathrm{bc}}$ \\
\hline SEM & & 40 & 0.16 & 0.09 \\
\hline$P$ value & & 0.036 & 0.017 & 0.017 \\
\hline
\end{tabular}

${ }_{a, b, c, d}$ Means in each column with different superscripts are significantly different at $P \leq 0.05$

OA: oak acorn, PEG: polyethylene glycol, BWG: bodyweight gain, FCR: feed conversion ratio

Values are means of four replicate pens, with 22 birds each

The current results showed that the dietary level of OA or PEG did not affect feed intake during the starter, finisher or entire period of the study. Also, there was no significant interaction between OA level and PEG for feed intake.

Current results (Table 4) indicated that dietary inclusion of OA impaired starter (days 1-21) FCR, depending on the level of inclusion. It means that feed was less efficiently utilized by birds fed 150 and 200 $\mathrm{g} / \mathrm{kg}$ OA compared with those fed diet without OA. Hence, the best and the worst FCR were observed in level of 0 and $200 \mathrm{~g} / \mathrm{kg} \mathrm{OA}$, respectively. Level $150 \mathrm{~g} / \mathrm{kg}$ was between 0 and $200 \mathrm{~g} / \mathrm{kg}$. Supplementation with PEG led to improved FCR at age 1 to 21 days (Table 4).

Significant interactions between OA level and PEG were observed for finisher and overall FCR (Table 5). During the finisher phase, the best $F C R$ was observed in treatment $0-P$ and $0+P$ which was significantly better than treatment 150-P and 200-P. It means that dietary inclusion of OA impaired FCR. Supplementation with PEG improved the FCR in birds given $150 \mathrm{~g} / \mathrm{kg}$ OA. Thus, treatment $150+P$ had better FCR compared to 150-P. As 2 treatments fed diets with same ingredients and nutrients, their difference in FCR can be contributed to PEG. Due to this improvement, significant difference in FCR was not observed between treatments $150+P, 0-P$ and $0+P$ which indicates that feed was converted with same efficiency by those treatments. According to this result, up to $150 \mathrm{~g} / \mathrm{kg}$ PEG-supplemented OA could be included in broiler diets, without negative effect on their feed efficiency. Treatment 200+P had worse FCR than treatment 0-P and $0+P$. It means that dietary inclusion of $200 \mathrm{~g} / \mathrm{kg} \mathrm{OA}$ may be too high and PEG could not prevent negative effect of this level of OA on FCR. Experimental treatments had same effects on overall (days 1-42) FCR.

Impaired performance of broilers given OA has been previously reported by other researchers. Rezaei \& Semnaninejad (2016) observed that feeding with OA reduced broiler performance when included at 100 and $200 \mathrm{~g} / \mathrm{kg}$ of diet. Similarly, Houshmand et al. (2015) found that using $150 \mathrm{~g} / \mathrm{kg}$ OA had negative consequences on broiler performance and tibia bone characteristics. In another study (Bouderoua et al., 2009), it was shown that broilers fed OA had lower bodyweight at 35 days of age. Indeed, FCR during 1-28 days of age negatively influenced by OA. However, such detrimental effects were not observed in last weeks of rearing period. Hence, final bodyweight (day 56) and overall FCR (days 1-56) were not significantly influenced by $O A$.

Growth-depressing effects on broilers of tannin-rich feedstuffs, particularly sorghum, have been shown in many studies. In a study conducted by Tandiang et al. (2014), replacing corn with conventional sorghum at the level of 333.3 or $500 \mathrm{~g} / \mathrm{kg}$ of diet impaired broilers' BWG and feed efficiency. This effect was attributed to the negative effects of sorghum tannins. Torres et al. (2013) reported that the replacement of $100 \%$ dietary corn with low-tannin sorghum had negative effects on that performance and intestinal mucosa of broiler chickens. Dei et al. (2008) stated that broilers fed diet containing shea nut meal (a high-tannin feed ingredient) had lower performance than those fed the control diet. Ebrahim et al. (2015) reported that dietary 
supplementation with 1\% TA significantly reduced feed intake and bodyweight of broilers reared under normal $\left(25^{\circ} \mathrm{C}\right)$ or chronic heat stress $\left(35^{\circ} \mathrm{C}\right)$ conditions.

Various reasons could account for the poor performance of broilers fed high-tannin diets: inhibition of enzymes involved in digestion of carbohydrates, proteins and fats (Jansman, 1993; Longstaff \& McNab,1991), reduction in mineral and vitamin availability (Jansman, 1993), alteration in metabolic pathway (Mansoori et al., 2007b; Mansoori \& Modirsanei, 2012), increase in the endogenous losses of protein and amino acids, particularly methionine, histidine and lysine (Mansoori \& Acamovic, 2007), and deleterious effects on internal organs such as the intestines, liver and pancreas (Ortiz et al., 1994). When one considers these adverse consequences, the growth-depressing effect of $O A$ is not surprising.

Significant interaction between $O A$ and PEG means that supplementation with PEG was effective in reducing the negative effects of $O A$ on $B W G$ and $F C R$, particularly when $150 \mathrm{~g} / \mathrm{kg} \mathrm{OA}$ was included in diets. On the other hand, PEG can improve the nutritive value of $O A$ for broilers. There are few reports on the effects of PEG on broilers fed high-tannin feedstuffs. Ford \& Hewitt (1979) found that PEG increased nitrogen digestibility in chicks fed high-tannin sorghum. In contrast, in another study the interaction between dietary addition of $15 \mathrm{~g} / \mathrm{kg} \mathrm{PEG}$ and various levels of tannin-containing rapeseed meal had no effect on male broiler performance (Karunajeewa et al., 1990).

However, more information is available regarding influences of PEG on the TA-fed broilers. In a study conducted by Mansoori et al. (2007a), broilers were given a diet without feed additive as the control or diets added with TA, PEG or TA + PEG. The TA-supplemented group had lower BWG and worse FCR compared to the control. Performance was significantly not influenced in birds given diet added with only PEG, while in broilers given diets containing TA, PEG increased BWG and improved FCR. It was suggested that PEG can make strong complexes with TA, thereby preventing its negative effects on dietary nutrients digestibility and utilization.

Because of disruption in trans-cellular and para-cellular pathways, tannins reduce the intestinal absorption of dietary nutrients and simple sugars such as D-xylose. The PEG can form complexes with tannins. Thus, there is not enough free tannin to influence the mechanisms responsible for the absorption of nutrients at cellular level (Mansoori et al., 2007b; Mansoori \& Modirsanei, 2012). As stated earlier, the digestion of dietary nutrients is affected adversely by tannins (Jansman, 1993), causing impaired performance. Recently, it has been reported that feeding with 100 and $200 \mathrm{~g} / \mathrm{kg}$ OA reduced DM and protein digestibility in broilers (Rezaei \& Semnaninejad, 2016). When one considers these effects, the improvement in performance of birds that were given the PEG-supplemented diets in the current study may be partially related to the positive effects of PEG on nutrient digestion and absorption in the intestine of the birds.

The effects of OA level and PEG on the relative weight (\% of BW) of liver and pancreas of broilers (Table 6), indicated that these parameters were not influenced significantly by OA level, PEG or their interaction at 21 and 42 days of age. There are inconsistent results on the effects of tannins on liver and pancreas weight. High levels of tannins have toxic effects on the liver and could increase the liver weight.

Table 6 Effects of oak acorn level and polyethylene glycol on relative weights of liver and pancreas at 21 and 42 days of age

\begin{tabular}{|c|c|c|c|c|c|c|c|c|c|c|c|}
\hline \multirow{2}{*}{ Parameter } & \multicolumn{3}{|c|}{$\begin{array}{c}\text { Dietary level of OA } \\
(\mathbf{g} / \mathbf{k g})\end{array}$} & \multirow{2}{*}{ SEM } & \multirow{2}{*}{$\begin{array}{c}P \\
\text { value }\end{array}$} & \multicolumn{2}{|c|}{ PEG } & \multirow{2}{*}{ SEM } & \multirow{2}{*}{$\begin{array}{c}P \\
\text { value }\end{array}$} & \multirow{2}{*}{ Interaction } & \multirow{2}{*}{$\underset{\text { value }}{\mathbf{P}}$} \\
\hline & 0 & 150 & 200 & & & without & with & & & & \\
\hline \multicolumn{12}{|l|}{ Liver } \\
\hline D 1-21 & 3.26 & 2.84 & 3.07 & 0.121 & 0.068 & 3.02 & 3.10 & 0.099 & 0.591 & NS & 0.19 \\
\hline D 22-42 & 2.24 & 2.48 & 2.42 & 0.097 & 0.218 & 2.44 & 2.31 & 0.079 & 0.257 & NS & 0.06 \\
\hline \multicolumn{12}{|l|}{ Pancreas } \\
\hline D 21 & 0.345 & 0.351 & 0.359 & 0.014 & 0.803 & 0.341 & 0.362 & 0.011 & 0.209 & NS & 0.96 \\
\hline D 42 & 0.203 & 0.220 & 0.223 & 0.011 & 0.422 & 0.193 & 0.241 & 0.009 & 0.615 & NS & 0.14 \\
\hline
\end{tabular}

Means in each row with different superscripts are significantly different at $P \leq 0.05$

OA: oak acorn, PEG: polyethylene glycol

NS: not significant

Values are means of 24 birds 
There is a threshold beyond which tannins may become toxic (Al-Mamary et al., 2001). However, in the current study, liver weight remained unaffected. Also in the current study, pancreas weight was not affected by OA, which is in line with other studies (Longstuff \& Mc Nab, 1991; Nyacotti et al., 1996). Conversely, in some previous studies (Ahmed et al., 1991; Mahmood et al., 2008), pancreatic hypertrophy was observed in broilers given high-tannin diets. Because pancreatic enzymes are inhibited by tannins, their production would be increased by the pancreas. This condition could increase the weight of the pancreas (Ahmed et al., 1991). Birds response to dietary tannins is influenced by factors such as the source of the tannins and feedstuffs, tannin concentration, animal species, age and production level, the response parameters (weight gain, feed intake and feed efficiency), length of the test period, and diet composition (level and source of protein) (Jansman, 1993). Thus, the inconsistency in the results may be related to these factors.

The effects of OA level and PEG on tibia characteristics at 21 and 42 days of age (Table 7) showed that birds given 150 and $200 \mathrm{~g} / \mathrm{kg}$ OA had lower tibia weight and length compared with those given diets

Table 7 Effects of oak acorn level and polyethylene glycol on tibia characteristics at 21 and 42 days of age

\begin{tabular}{|c|c|c|c|c|c|c|c|c|c|c|c|}
\hline \multirow{2}{*}{ Parameter } & \multicolumn{3}{|c|}{$\begin{array}{c}\text { Dietary level of OA } \\
(\mathrm{g} / \mathrm{kg})\end{array}$} & \multirow{2}{*}{ SEM } & \multirow{2}{*}{$\begin{array}{c}P \\
\text { value }\end{array}$} & \multicolumn{2}{|c|}{ PEG } & \multirow{2}{*}{ SEM } & \multirow{2}{*}{$\begin{array}{c}\mathbf{P} \\
\text { value }\end{array}$} & \multirow{2}{*}{ Interaction } & \multirow{2}{*}{$\stackrel{P}{P}$} \\
\hline & 0 & 150 & 200 & & & without & with & & & & \\
\hline \multicolumn{12}{|l|}{ Weight (g) } \\
\hline D 21 & $2.36^{\mathrm{a}}$ & $1.89^{\mathrm{b}}$ & $1.78^{\mathrm{b}}$ & 0.061 & 0.0001 & $2.09^{\mathrm{a}}$ & $1.93^{\mathrm{b}}$ & 0.050 & 0.0402 & NS & 0.50 \\
\hline D 42 & $6.71^{\mathrm{a}}$ & $5.75^{b}$ & $5.49^{b}$ & 0.281 & 0.011 & 5.97 & 5.99 & 0.229 & 0.95 & NS & 0.76 \\
\hline \multicolumn{12}{|l|}{ Length $(\mathrm{cm})$} \\
\hline D 21 & $6.83^{\mathrm{a}}$ & $6.43^{\mathrm{b}}$ & $6.39^{\mathrm{b}}$ & 0.051 & 0.0001 & 6.61 & 6.49 & 0.042 & 0.058 & NS & 0.43 \\
\hline D 42 & $9.91^{\mathrm{a}}$ & $9.32^{b}$ & $9.46^{\mathrm{b}}$ & 0.127 & 0.007 & 9.63 & 9.50 & 0.103 & 0.36 & NS & 0.67 \\
\hline \multicolumn{12}{|c|}{ Volume $\left(\mathrm{cm}^{3}\right)$} \\
\hline D 21 & $2.16^{\mathrm{a}}$ & $1.96^{\mathrm{ab}}$ & $1.89^{b}$ & 0.070 & 0.021 & 2.08 & 1.92 & 0.057 & 0.0375 & NS & 0.52 \\
\hline D 42 & 6.59 & 5.73 & 5.83 & 0.283 & 0.08 & 6.01 & 6.09 & 0.231 & 0.80 & NS & 0.97 \\
\hline \multicolumn{12}{|l|}{ Density } \\
\hline D 21 & $1.59^{\mathrm{a}}$ & $0.96^{\mathrm{b}}$ & $0.95^{\mathrm{b}}$ & 0.044 & 0.0195 & 1.04 & 1.01 & 0.035 & 0.97 & NS & 0.32 \\
\hline D 42 & 1.019 & 1.00 & 0.96 & 0.022 & 0.08 & 1.00 & 0.98 & 0.018 & 0.80 & NS & 0.30 \\
\hline \multicolumn{12}{|l|}{ Ash (\%) } \\
\hline D 21 & 51.21 & 49.31 & 48.43 & 1.369 & 0.36 & 48.43 & 50.65 & 1.117 & 0.22 & NS & 0.13 \\
\hline D 42 & $43.72^{\mathrm{a}}$ & $45.19^{a}$ & $41.97^{b}$ & 0.567 & 0.0032 & $42.88^{\mathrm{b}}$ & $44.37^{\mathrm{a}}$ & 0.463 & 0.03 & NS & 0.14 \\
\hline \multicolumn{12}{|c|}{ Bone ash weight / length Index } \\
\hline D 21 & $14.95^{\mathrm{a}}$ & $13.42^{\mathrm{ab}}$ & $12.65^{b}$ & 0.573 & 0.032 & 13.85 & 13.76 & 0.468 & 0.78 & NS & 0.37 \\
\hline D 42 & $27.78^{\mathrm{a}}$ & $26.01^{a}$ & $22.53^{b}$ & 1.062 & 0.008 & 25.35 & 25.52 & 0.867 & 0.89 & NS & 0.051 \\
\hline \multicolumn{12}{|c|}{ Robsticity Index } \\
\hline D 21 & 5.15 & 5.17 & 5.21 & 0.065 & 0.78 & 5.14 & 5.22 & 0.053 & 0.33 & NS & 0.58 \\
\hline D 42 & 5.20 & 5.21 & 5.35 & 0.079 & 0.35 & 5.26 & 5.24 & 0.064 & 0.80 & NS & 0.06 \\
\hline \multicolumn{12}{|l|}{ Calcium (\%) } \\
\hline D 21 & 25.29 & 26.15 & 24.77 & 0.64 & 0.06 & 25.74 & 28.99 & 0.52 & .075 & NS & 0.11 \\
\hline D 42 & 26.18 & 26.64 & 26.71 & 0.81 & 0.88 & 26.68 & 26.35 & 0.66 & 0.73 & NS & 0.27 \\
\hline \multicolumn{12}{|c|}{ Phosphorus (\%) } \\
\hline D 21 & 9.66 & 9.95 & 10.00 & 0.20 & 0.42 & 10.01 & 9.70 & 0.20 & 0.15 & NS & 0.52 \\
\hline D 42 & $9.47^{b}$ & $9.67^{b}$ & $10.66^{\mathrm{a}}$ & 0.27 & 0.013 & 9.87 & 10.00 & 0.20 & 0.69 & NS & 0.07 \\
\hline
\end{tabular}

${ }^{a, b}$ Means in each row with different superscripts are significantly different at $P \leq 0.05$

OA: oak acorn, PEG: polyethylene glycol

*Robusticity index was calculated using tibia length / cube root of tibia weight

NS: not significant

Values are means of 24 birds 
without $O A$ on days 21 and 42, and lower density at 21 days of age. Also, tibia volume was reduced in 200 $\mathrm{g} / \mathrm{kg}$ compared with $0 \mathrm{~g} / \mathrm{kg} O A$ at 21 days of age. In addition, feeding with $200 \mathrm{~g} / \mathrm{kg} \mathrm{OA}$ significantly reduced bone ash at 42 days of age and bone ash weight length index at 21 and 42 days of age. Supplementation with PEG significantly reduced weight of tibia at 21 days of age but increased tibia ash at 42 days of age.

Various criteria such as bone weight, volume, ash and bone breaking strength are used as indicators of bone mineralization and status in poultry (Rao et al., 1993). The robusticity index and bone ash weight / bone length index (Reisenfeld, 1972; Seedor et al., 1991) are also important. Based on these parameters, feeding with $200 \mathrm{~g} / \mathrm{kg}$ OA impaired tibia bone status, which was reflected in the lower bone ash weight / bone length index on days 21 and 42 , as well as lower ash on day 42.

Dietary minerals play a vital role in bone status and health (Proszkowiec-Weglarz \& Angel, 2013). On the other hand, mineral availability and absorption are influenced negatively by tannins (Jansman, 1993). Feeding with high-tannin diets reduces the apparent absorption of dietary minerals such as calcium, phosphorus, magnesium, sodium, iron and cobalt in broilers and layer hens (Hassan et al., 2003; Mahmood et al., 2014). The OA is high in tannins. Thus, it is not surprising if OA-fed birds have impaired tibia characteristics. No interactions were found between OA level and PEG for tibia characteristics on days 21 and 42.

\section{Conclusions}

The results of the current study indicated that the dietary inclusion of 150 and $200 \mathrm{~g} / \mathrm{kg} \mathrm{OA}$ had deleterious effects on broiler performance (lower BWG and poorer FCR). Also, feeding with $200 \mathrm{~g} / \mathrm{kg} \mathrm{OA}$ negatively influenced some tibia characteristics. Owing to the significant interaction between $O A$ level and PEG, supplementation with this additive could alleviate the deleterious effects of OA on broiler performance, particularly when up to $150 \mathrm{~g} / \mathrm{kg}$ OA is included in their diets.

\section{Acknowledgments}

The authors would like to thank Yasouj University, Yasouj, Iran, for providing support for this study.

\section{Authors' Contributions}

FS and MH designed and conducted the project and did the farm measurements. SP and MZ participated in

laboratory measurements, data analysis and writing the manuscript.

\section{Conflict of Interest Declaration}

The authors declare that they have no conflicts of interest.

\section{References}

Ahmed, A.E., Smithard, R. \& Ellis, M., 1991. Activities of enzymes of the pancreas, and the lumen and mucosa of the small intestine in growing broiler cockerels fed on tannin-containing diets. Br. J. Nut. 65, 189-197.

Al-Mamary, M., Al-Habori, M., Al-Aghbari, A. \& Al-Obeidi, A., 2001. In vivo effects of dietary sorghum tannins on rabbit digestive enzymes and mineral absorption. Nut. Res. 21, 1393-1401.

AOAC, 1995. Official methods of analysis (16th ed). Association of Official Analytical Chemists, Washington, USA.

Bouderoua, K., Mourot, J. \& Selselet-Attou, G., 2009. The effect of green oak acorn (Quercus ilex) based diet on growth performance and meat fatty acid composition of broilers. Asian-Aust. J. Anim. Sci. 6, 843-848.

Dei, H.K., Rose, S.P., Mackenzie, A.M. \& Amarowicz, R. 2008. Growth performance of broiler chickens fed diets containing shea nut (Vitellaria paradoxa Gaertn.) meal fermented with Aspergillus niger. Poult. Sci. 87, 17731778.

Ebrahim, R., Liang, J.B., Faseleh Jahromi, M., Shokryazdan, P., Ebrahimi, M., Chen, W.L.\& Goh, Y.M. 2015. Effects of tannic acid on performance and fatty acid composition of breast muscle in broiler chickens under heat stress. Italian J. Anim. Sci. 14, 572-577.

Ford, J.E. \& Hewitt, D. 1979. Protein quality in cereals and pulses. 3. Bioassay with rats and chickens on sorghum (Sorghum vulgare Pers.), barley and field beans (Vicia faba L.). Influence of polyethylene glycol on digestibility of the protein in high-tannin grain. Bri. J. Nut. 42, 325-340.

Hassan, I.A.G., Elzubeir, E.A. \& El Tinay, A.H., 2003. Growth and apparent absorption of minerals in broiler chickens fed diets with low and high tannin contents. Trop. Anim. Health Prod. 35, 189-196.

Houshmand, M., Hojati, F. \& Parsaie, S., 2015. Dietary nutrient manipulation to improve the performance and tibia characteristics of broilers fed oak acorn (Quercus brantii Lindl). Braz. J. Poult. Sci. 17, 17-24.

Jansman, A.J.M., 1993. Tannins in feedstuffs for simple-stomached animals. Nut. Res. Rev. 6, 209-236.

Karunajeewa, H., ljagbuji, E.G. \& Rreece, R.L.1990. Effect of dietary levels of rapeseed meal and polyethylene glycol on the performance of male broiler chickens. Br. Poult. Sci. 31, 545-555.

Longstaff, M. \& Mc Nab, J.M., 1991.The inhibitory effects of hull polysaccharides and tannins of field beans (Vicia faba L.) on the digestion of amino acids, starch and lipid and on digestive enzymes activities in young chicks. Br. J. Nut. 65,199-216. 
Mahmood, S., Ajmal Khan, M., Sarwer, M. \& Nisa, M. 2008. Use of chemical treatments to reduce antinutritional effects of tannins in sal seed meal: Effect on performance and digestive enzymes of broilers. Livest. Sci. 116, 162-170.

Mahmood S, Ali, H., Ahmad, F. \& Iqbal, Z., 2014. Estimation of tannins in different sorghum varieties and their effects on nutrient digestibility and absorption of some minerals in caged White Leghorn layers. Int. J. Agric. Biol. 16, 217221.

Makkar, H.P.S., 2003. Quantification of tannins in tree and shrub foliage. A laboratory manual. FAO/IAEA.

Manssori, B. \& Acamovic, T., 2007. The effect of tannic acid on the excretion of endogenous methionine, histidine and lysine with broilers. Anim. Feed Sci. Technol. 134, 198-210.

Mansoori, B. \& Modirsanei, M., 2012. The effect of tannic acid and polyethylene glycol on the absorption capacity of chicken intestine for $d$-xylose and $\beta$-carotene. J. Anim. Physiol. Anim. Nutr. 96, 47-51.

Mansoori, B., Nodeh, H., Modirsanei, M., Kiaei M.M. \& Farkhoy, M. 2007a. Influence of dietary tannic acid and polyethylene glycol on growth and intestinal D-xylose absorption of broiler cockerels and activity of serum enzymes. Br. Pout. Sci. 48, 489-495.

Mansoori, B., Nodeh, H., Modirsanei, M., Kiaei M.M. \& Farkhoy, M. 2007b. Evaluating the influence of tannic acid alone or with polyethylene glycol on the intestinal absorption capacity of broiler chickens, using d-xylose absorption test. Anim. Feed Sci. Technol. 134, 252-260.

Medugu, C.I., Saleh, B., Igwebuike, J.U. \& Ndirmbita, R.L., 2012. Strategies to improve the utilization of tannin-rich feed materials by poultry. Int. J. Poult. Sci. 11, 417-423.

Midilli, M., Muglali, Ö.H., Altıntas, L., Erol, H. \& Cakır, S., 2008. Shelled acorn seed (Quercus cerris) as a diet ingredient on the performance of growing Japanese Quail. S. Afr. J. Anim. Sci. 38, 38-42.

Mlambo, V., Marume, U. \& Gajana, C.S. 2015. Utility of the browser's behavioural and physiological strategies in coping with dietary tannins: Are exogenous tannin-inactivating treatments necessary? S. Afr. J. Anim. Sci. 45, 441-151.

NRC. 1994. Nutrient requirements of poultry. National Academy Press, Washington, DC.

Nyachoti, C.M., Atkinson, J.L. \& Lesson, S., 1996. Response of broiler chicks fed a high-tannin sorghum diets. J Appl. Poult. Res. 5, 239-245.

Ortiz, L.T., Alzueta, C., Trevino, J. \& Castano, M., 1994. Effects of faba bean tannins on the growth and histological structure of the intestinal tract and liver of chicks and rats. Br. Poult. Sci. 35, 743-754.

Proszkowiec-Weglarz, M. \& Angel, R. 2013. Calcium and phosphorus metabolism in broilers: Effect of homeostatic mechanism on calcium and phosphorus digestibility. J. Appl. Poult. Res. 22, 609-627.

Rao S.K., West M.S., Frost T.J., Orban, J.I., Bryant M.M. \& Roland, SRDA. 1993. Sample size required for various methods of assessing bone status in commercial Leghorn hens. Poult. Sci. 72, 229-235.

Reisenfeld, A., 1972. Metatarsal robusticity in bipedal rats. Am. J. Phys. Anthropol. 40, 229-234.

Rezaei, M. \& Semnaninejad, H., 2016. Effects of different levels of raw and processed oak acorn (Quercus castaneifolia) on performance, small intestine morphology, ileal digestibility of nutrients, carcass characteristics and some blood parameters in broiler chickens. Poult. Sci. J. 4, 127-138.

Saffarzadeh, A., Vincze, L. \& Csap, J., 1999. Determination of the chemical composition of acorn (Quercus branti), Pistacia atlantica and Pistacia Khinjuk seed as non-conventional feedstuff. Acta Agraria Kaposváriensis. 3, 59-69.

SAS, 2005. Statistical Analysis Systems users guide (9th ed.). SAS Institute Inc., Cary, N.C., USA.

Seedor, J.G., Quarruccio, H.A. \& Thompson, D.D., 1991. The bisphosphonate alendronate (MK-217) inhibits bone loss due to ovariectomy in rats. J. Bone and Min. Res. 6, 339-346.

Sinaei, K.h. \& Houshmand, M., 2016. Effects of dietary inclusion of raw or treated Iranian acorn (Quercus brantii Lindl) on the performance and cecal bacteria of broilers. Poult. Sci. J. 4, 73-79.

Shimada, T., 2001. Nutrient compositions of acorns and horse chestnuts in relation to seed hoarding. Ecol. Res. 16, 803808.

Tandiang, D.M., Diop, M.T., Dieng, A., Yoda, G.M.L., Cisse, N. \& Nassim, M. 2014. Effect of corn substitution by sorghum grain with low tannin content on broilers production: Animal performance, nutrient digestibility and carcass characteristics. Int. J. Poult. Sci. 13, 568-574.

Torres, K.A.A., Pizauro Jr., J.M., Soares, C.P., Silva, T.G.A., Nogueira, W.C.L., Campos, D.M.B., Furlan, R.L., \& Macari, M. 2013. Effects of corn replacement by sorghum in broiler diets on performance and intestinal mucosa integrity. Poult. Sci. 92, 1564-1571. 